\title{
Analysis of the collagen fibers on autopsied patients' uterus with the Acquired Immunodeficiency Syndrome
}

\author{
Bianca Gonçalves Silva Torquato 1 \\ Mariana Silva Oliveira 2 \\ Guilherme Ribeiro Juliano 3 \\ Laura Sanches Aguiar 4 \\ Gabriela Ribeiro Juliano 5 \\ Luciano Matias da Silveira 6 \\ Ana Paula Espíndula 7 \\ Lívia Ferreira Oliveira 8 \\ Camila Lourencini Cavellani 9 \\ Flávia Aparecida de Oliveira 10 \\ Vicente de Paula Antunes Teixeira 11 \\ Mara Lúcia Fonseca Ferraz 12
}

1-12 Universidade Federal do Triângulo Mineiro. Av. Frei Paulino, 30, Nossa Senhora da Abadia. Uberaba, MG, Brasil. CEP: 38025-180. E-mail: biatorquato@gmail.com

\begin{abstract}
Objectives: to compare the percentage of collagen fibers in the autopsied women's uterine body and cervix with and without the Acquired Immunodeficiency Syndrome (Aids).

Methods: 30 autopsied women's medical files were selected from 1988 to 2013. 30 fragments of the uterine body and 30 cervix were collected and then divided into two groups, 15 with Aids and 15 without, The quantification of the collagen fibers of the uterine body and cervix was performed on slides stained with picrosirius, using the KS-300巴 system.

Results: the percentage of collagen fibers was lower for cervix ( $U=336544 ; p=0.001)$ and higher for the uterine body $(U=308726,5 ; p=0.004)$ in the retroviral group when compared to the group without the disease. The percentage was higher for cervix than the uterine body in the group with Aids $(t=0,4793$; $p=0.0031)$. the same result was found in the group without Aids ( $t=2,397 ; p=0.0637)$.

Conclusions: the increase in the percentage of collagen fibers in the uterine body of women with Aids' indicates an immune response for viral infection and reveals a failure in keeping the infection restricted to the cervix. The interpretation of the histochemical and morphometric parameters can be useful in the diagnosis associated to HIV infection, contributing for clinical improvement and life expectancy.
\end{abstract}

Key words Acquired immunodeficiency syndrome, Cervix; Collagen, Autopsy 


\section{Introduction}

Sexually transmitted infections (STIs) continue to be a major public health problem in Brazil from 2007 to June 2016. 136,945 cases of human immunodeficiency virus (HIV) infection were reported in the Sistema de Notificação de Lesões (SINAN) ${ }^{1}$ (Notification System on Lesions). And during this period, a total of 44,766 cases of only women, were reported by SINAN. 1

Women with Acquired Immunodeficiency Syndrome (Aids) present a decrease on the cervical epithelium, esophageal and skin, ${ }^{2-4}$ and the first line of defense against HIV acquisition in the female genital tract is the mucosal lining of the epithelial barrier. 5 Studies demonstrate that HIV can interact by means of gp 120 with immune cells which activate local inflammatory responses and repairs. 6 However, sometimes this interaction may occur by producing inappropriate activations ${ }^{7}$ and increase the production of collagen and monocyte chemoattractant protein (a macrophage chemoattractant). 8

The cervix is a dense fibrous tissue that is located at the lowest part of the uterus. ${ }^{9}$ The cervical mechanical activity has two functions: before childbirth, it should remain closed and resist to the mechanical load of the pregnancy and at the moment of childbirth it should be soft to be deformed and dilated allowing a passage for the fetus. 10 The organization of the collagen in the human cervical tissue plays an important role in the structural function of the tissue. 11

The cervical collagen is like fibers in a hierarchical network embedded in a superficial viscous substance of glycosaminoglycans negatively charged and other proteins. 10 The collagen (types I and III) compose of 34 to $77 \%$ of dry weight, 12,13 with evidence in studies on human tissues that this dry weight content remains constantly during the gestation. ${ }^{14}$ In general, the collagen fiber network is reported to be anisotropic with different orientations in distinct anatomical regions within the cervix. 15

Patients with Aids usually present an increased number of collagen fibers due to the deterioration of the natural immune mechanisms, the susceptibility to viral, fungal, bacterial, and parasitic agents as well as the occurrence of non-infectious inflammatory diseases. ${ }^{2}$

The purpose of this study was to compare the percentage of collagen fibers in the uterine body and cervix of autopsied women with and without Aids. Thus, this study intends to contribute for a better understanding on the influence of Aids on uterine changes.

\section{Method}

This study was approved by the Research Ethics Committee at the Universidade Federal do Triângulo Mineiro (UFTM) under the protocol number 2689.

It is a quantitative, cross-sectional and descriptive study. We analyzed retrospectively a total of 482 autopsy protocols at the Hospital de Clínicas da Universidade Federal do Triângulo Mineiro (HCUFTM), Uberaba City, Minas Gerais State in the period of 1988 to 2013. From these protocols, 15 autopsied women diagnosed with Aids were selected (Figure 1). The selection criteria were ages $>18$ years old and females. Women whose autopsy protocols were incomplete and did not have the uterus in good condition for analysis were excluded. In addition, for the selected group, the diagnosis for Aids was made by the evidence of at least one of the diseases defining the syndrome presented at the time of autopsy and the CD4+ T lymphocyte count below 200 cells $/ \mathrm{mm}^{3} .16$ The anatomopathological diagnosis performed by the two medical pathologists also reported that the cause of death of all the selected women with Aids for the present study was infectious disease. For the comparison criteria, 15 autopsied women without Aids were selected for a control group in the same period were paired for the study group according to the variables:, age, skin color (white or non-white) and the Body Mass Index (BMI).

In the cervix, a fragment of approximately 3 millimeters $(\mathrm{mm})$ thick was removed by a mediated section. In the uterine body, a cut was made on the uterine wall where the epithelium was preserved and, a fragment of approximately 3 millimeters $(\mathrm{mm})$ was removed. Thus, in both groups, 15 fragments of the uterine body and 15 fragments of the cervix constituted of 60 fragments altogether.

The fragments were fixed in 10\% formaldehyde and dehydrated in increasing concentrations of alcohol (70 to $100 \%$ ), diaphanized in xylol and included in paraffin. The slides were made in serial cut of $4 \mu \mathrm{m}$ thick. The fragments were put on the glass slides with poly-L-lysine ${ }^{\circledR}$ and processed for histochemistry.

To quantify the percentage of collagen fibers in the uterine body and cervix, the slides were stained with picrosirius and examined under $40 x$ objective polarized light (1600x final increase), the digitalized image showed a constructed area of collagen, with an aspect of birefringence and a reddish coloration. The quantification was performed on the entire length of the slides using the KS-300 ${ }^{\circledR}$ system, in 
Flowchart of the study sample.

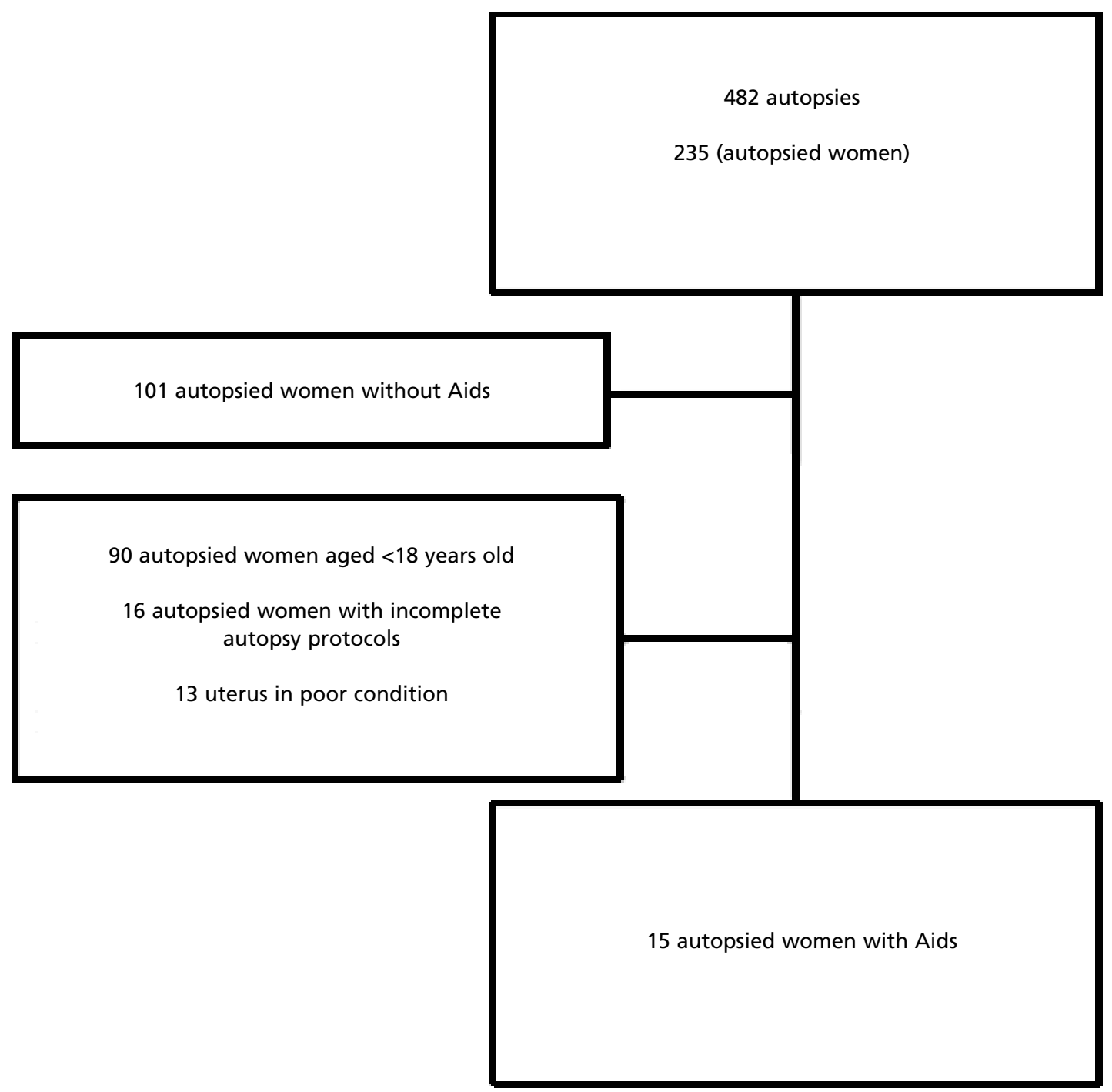


which the observer marked the collagen fibers to obtain the percentage of these fibers by field area analyzed, and the number of fields varied from 18 to 42.

The statistical analysis used the SigmaStat ${ }^{\circledR} 2.03$ software. The quantitative variables were tested for normality by Kolmogorov-Smirnov test. The parametric Student's t-test was applied to compare the two groups with normal distribution and homogeneous variance variables. The non-parametric MannWhitney (U) test was used to compare the two groups with non-normal distribution and non-homogeneous variance variables. The differences were considered statistically significant with $p<0.05$.

\section{Results}

The groups were paired according to age $(\mathrm{t}=1.326$; $p<0.001)$, BMI $(\mathrm{t}=6.165 ; p<0.002)$ and skin color (white or non-white). Of the 30 women selected, the mean age was $37.40 \pm 7.16$ years old in the retroviral group and $38.20 \pm 8.00$ years old in the group without Aids and the age was between 25 and 49 years old in both groups. Among the women with Aids, $8(53.3 \%)$ were classified as white, the same with the women without Aids. The BMI in the group with Aids was $22.20 \pm 4.08 \mathrm{~kg} / \mathrm{m}^{2}$ and in the group without Aids was $26.83 \pm 4.86 \mathrm{~kg} / \mathrm{m}^{2}$.

The percentage of collagen fibers in the cervix was significantly lower in the group with Aids $(\mathrm{U}=336544 ; p=0.001$ ) (Table 1, Figure 2) when compared to the group without the disease.

In the comparison of the percentage of collagen fibers in the uterine body, the group with Aids presented a significantly higher percentage than the group without Aids $(\mathrm{U}=308726 ; p=0.004)$ (Table 1, Figure 3).

Table 1

Comparison of the percentage of collagen fibers of the cervix and the uterine body among a group of women with and without Aids.

\begin{tabular}{|c|c|c|c|c|c|c|}
\hline \multirow[t]{2}{*}{ Group } & \multirow[t]{2}{*}{$\mathbf{N}$} & \multirow[t]{2}{*}{$\%$} & $\begin{array}{c}\text { Percentage of } \\
\text { collagen fibers } \\
\text { of the cervix } \\
(\%)\end{array}$ & \multirow[t]{2}{*}{$p$} & $\begin{array}{l}\text { Percentage of } \\
\text { collagen fibers of } \\
\text { the uterine body } \\
(\%)\end{array}$ & \multirow[t]{2}{*}{$p$} \\
\hline & & & Median (25\%-75\%) & & Median (25\%-75\%) & \\
\hline \multirow[t]{2}{*}{ With Aids } & 15 & 50 & $20.17(11.51-28.13)^{1}$ & & $20.09(15.06-24.21)^{2}$ & \\
\hline & & & & 0.001 & & 0.004 \\
\hline Without Aids & 15 & 50 & $23.23(14.54-31.20)^{1}$ & & $19.20(13.70-23.07)^{2}$ & \\
\hline Total & 30 & 100 & & & & \\
\hline
\end{tabular}

$1 \mathrm{U}=336544 ; 2 \mathrm{U}=308726$

The non-parametric Mann-Whitney $(U)$ test. 
Microscopic analysis of collagen fibers indicated by yellow arrows of the cervix through optic microscopy. (Picrosirius, 1600X).

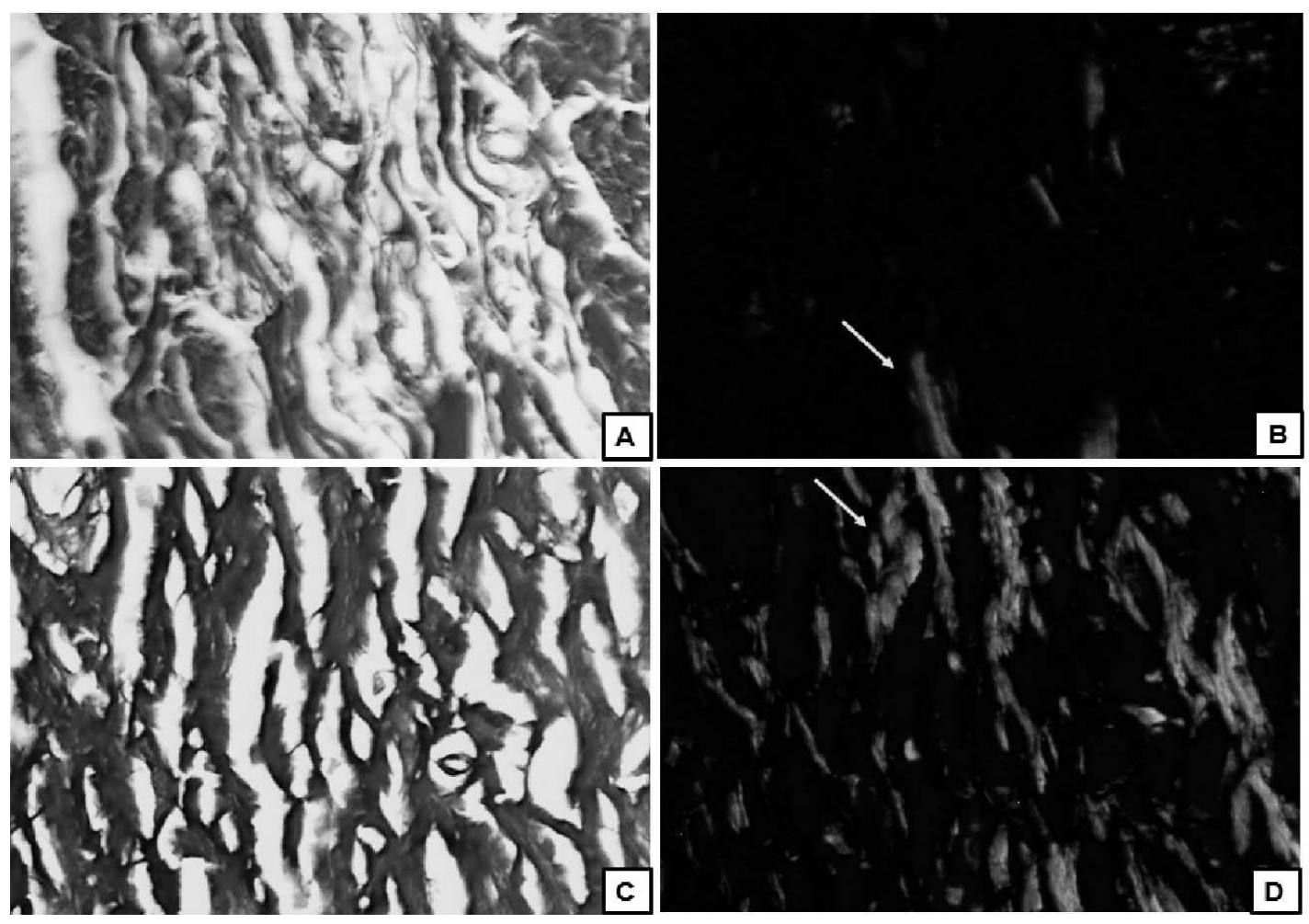

(A) collagen fibers of a woman with Aids under common light; (B) collagen fibers of a woman with Aids under polarized light; (C) collagen fibers of a woman without Aids under common light; (D) collagen fibers of a woman without Aids under polarized light. 
Figure 3

Microscopic analysis of the collagen fibers indicated by yellow arrows of the uterine body by optic microscopy. (Picrosirius, $1600 \mathrm{X}$ ).

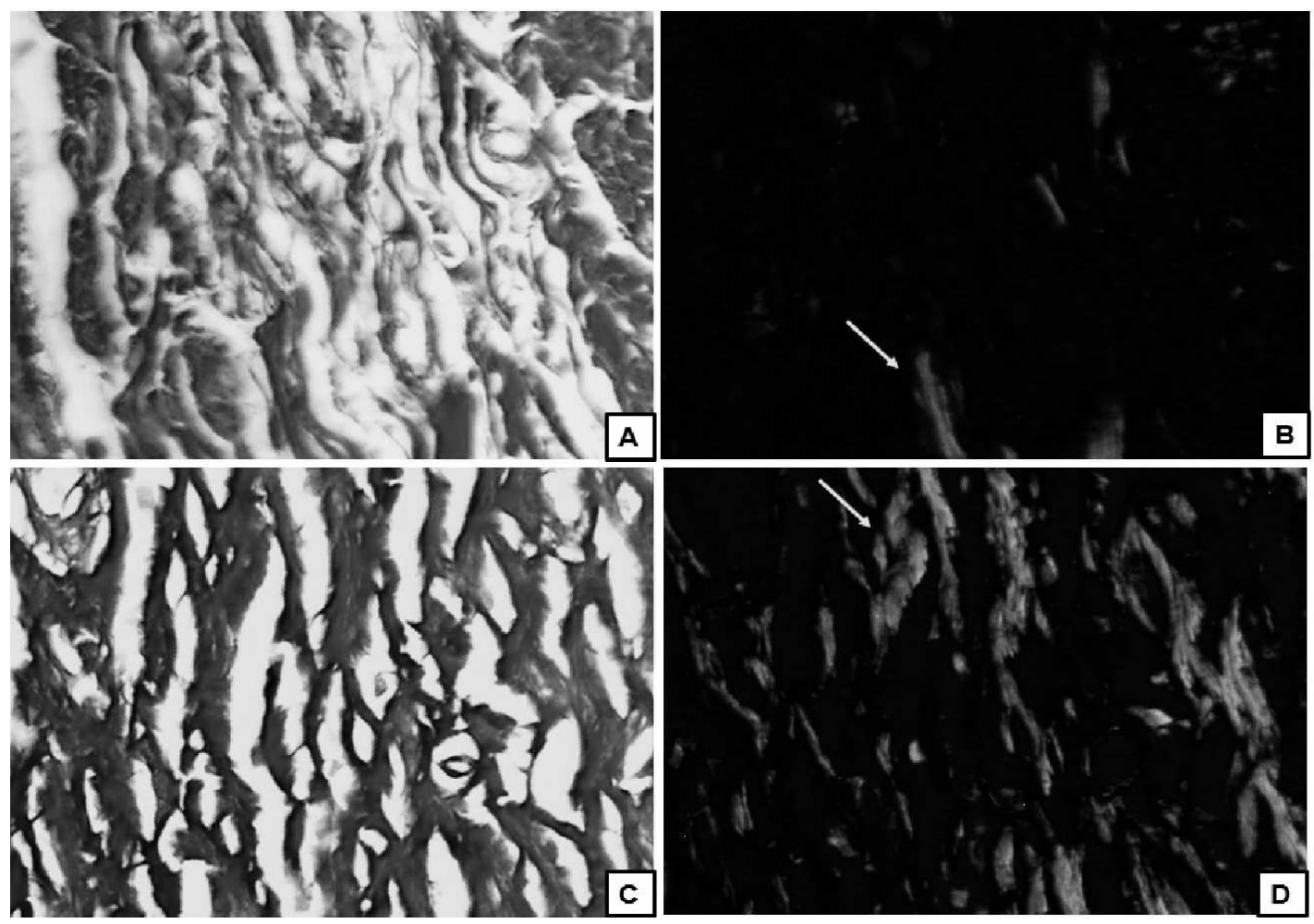

(A) collagen fibers of a woman with Aids under common light; (B) collagen fibers of a woman with Aids under polarized light; (C) collagen fibers of a woman without Aids under common light; (D) collagen fibers of a woman without Aids under polarized light.

Table 2

Comparison of the percentage of collagen fibers of the cervix and the percentage of collagen fibers of the uterine body in a group of women with and without Aids.

\begin{tabular}{|c|c|c|c|c|c|c|}
\hline \multirow{2}{*}{ Group } & \multirow{2}{*}{$\mathbf{N}$} & \multirow{2}{*}{$\%$} & With Aids & \multirow{2}{*}{$p$} & Without Aids & \multirow{2}{*}{$p$} \\
\hline & & & $\bar{X} \pm D P$ & & $\bar{x} \pm D P$ & \\
\hline $\begin{array}{l}\text { Percentage of } \\
\text { collagen fibers } \\
\text { of the cervix }\end{array}$ & 15 & 50.0 & $20.83 \pm 2.261$ & & $24.40 \pm 2.172$ & \\
\hline$(\%)$ & & & & 0.003 & & 0.06 \\
\hline $\begin{array}{l}\text { Percentage of } \\
\text { collagen fibers } \\
\text { of the uterine } \\
\text { body }(\%)\end{array}$ & 15 & 50.0 & $19.65 \pm 0.971$ & & $18.35 \pm 1.292$ & \\
\hline Total & 30 & 100.0 & & & & \\
\hline
\end{tabular}

$1 \mathrm{t}=0.4793 ; 2 \mathrm{t}=2.397$

The parametric Student's $t(t)$ test. 
Table 3

Description of the cause of death and other infections in a group of women with and without Aids.

\begin{tabular}{|c|c|c|c|c|c|c|c|}
\hline Group & $\mathbf{N}$ & $\%$ & Syphilis & HPV & Herpes & Hepatitis B & Cause of death \\
\hline With & & & No & No & No & No & Aids \\
\hline \multirow[t]{14}{*}{ AIDS } & & & No & No & No & No & Aids \\
\hline & & & No & No & No & No & Aids \\
\hline & & & No & No & No & No & Aids \\
\hline & & & No & No & No & No & Aids \\
\hline & & & No & No & No & No & Aids \\
\hline & & & No & No & No & No & Aids \\
\hline & & & No & No & No & No & Aids \\
\hline & & & No & No & No & No & Aids \\
\hline & & & No & No & No & No & Aids \\
\hline & & & No & No & No & No & Aids \\
\hline & & & No & No & No & No & Aids \\
\hline & & & No & No & No & No & Aids \\
\hline & & & No & No & No & No & Aids \\
\hline & & & No & No & No & No & Aids \\
\hline Total & 15 & 50.0 & & & & & \\
\hline Without & & & No & No & No & No & Hemorrhagic peritonitis \\
\hline \multirow[t]{14}{*}{ AIDS } & & & No & No & No & No & Chronic nephropathy \\
\hline & & & No & No & No & No & Bronchopneumonitis \\
\hline & & & No & No & No & No & Hypertensive cardiopathy \\
\hline & & & No & No & No & No & Pulmonary nocardiosis \\
\hline & & & No & No & No & No & Hypertensive cardiopathy \\
\hline & & & No & No & No & No & SARS \\
\hline & & & No & No & No & No & Pulmonary carcinoma \\
\hline & & & No & No & No & No & Brain aneurysm \\
\hline & & & No & No & No & No & Systemic amyloidosis \\
\hline & & & No & No & No & No & Alcoholic hepatitis \\
\hline & & & No & No & No & No & Atherosclerotic Arteriosclerosis \\
\hline & & & No & No & No & No & Atherosclerotic Arteriosclerosis \\
\hline & & & No & No & No & No & Hypertensive cardiopathy \\
\hline & & & No & No & No & No & Gastric adenocarcinoma \\
\hline Total & 15 & 50.0 & & & & & \\
\hline
\end{tabular}

SARS (Severe acute respiratory syndrome). 
In the comparison of the percentage of collagen fibers in the cervix with the percentage of collagen fibers in the uterine body in the group of women with Aids, the percentage in the cervix was significantly higher ( $\mathrm{t}=0.479 ; p=0.003$ ) (Table 2 ). The same result was obtained in the group without Aids $(\mathrm{t}=2.397 ; p=0.064)$ (Table 2).

Table 3 shows the causes of death and possible infections present in both groups.

\section{Discussion}

The women with Aids presented significantly a lower percentage of collagen fibers in the cervix when compared to the group without the syndrome. The comparison of the percentage of collagen fibers in the cervix with the percentage of collagen fibers in the uterine body in the group with Aids, the percentage in the uterine body was significantly higher. According to the medical literature, patients with Aids usually have an increase in the amount of collagen fibers. This increase is associated to the activation and inflammation of the immune system in a chronic form in these locations. 2 The imbalance between CD4 and CD8 cells seen in HIV infection can lead to alterations in the cytokine profiles with the reduction in anti-fibrotic cytokines mediated by a decrease of the interferon (IFN)-gamma from Th1 cells and an increase in the profibrotic cytokines (IL4, IL-5, IL-10 and IL-13) due to a relative increase in the TH2 signal. 17,18

In addition to the infectious process, other factors may also alter the levels of cytokines in the genital fluids, such as oral contraceptive use, pregnancy, age and the use of vaginal antiseptics. 19 However, studies show that in chronic HIV infection, the epithelial cells, fibroblasts and the immune cells that reside in the female reproductive tract tissues contribute to the pool of cytokines, chemokines and growth factors present in the sexual hormones tissue environment, estradiol and progesterone. 20 Since fibroblasts respond to several immunological mediators, the immune alterations in patients with HIV could affect their functions, leading to modifications in the responses of producing and/or reducing collagen fibers. ${ }^{21}$

In this present study, a significantly higher percentage of collagen fibers was detected in the uterine body of patients with Aids when compared to the group without Aids. When the upper tract genital epithelial cells are exposed to HIV, the mucosal barrier is compromised and along with the proinflammatory cytokines secretion action by the epithelial cells. 22 The secretions by the epithelial cells from the female reproductive tract have significant effects in determining whether or not an HIV infection will occur. For example, many of these epithelial cell factors are chemokines/cytokines that attract/activate the immune cells at the location of the HIV infection. ${ }^{23}$ The number of activated HIV target cells $(\mathrm{CD} 4+\mathrm{T}$ cells, macrophages and dendritic cells) present at the point of the virus, may increase chances for the infection to occur. Alternatively, some of the same factors have antiHIV activity and prevent the HIV infection to develop. This apparent paradox in relation to the HIV infection is dependent on many factors, including the quantity of the epithelial factors secretion is in the female reproductive tract, the presence of co-infecting pathogens, the presence of proteolytic enzymes, the sexual hormone balance, the activation of cells status, the interaction of other secreted factors by other cells as well as the epithelial cells and the present types of immune cells. 20

In the uterus during the proliferative phase, the aggregated lymphoid consist of cell groups CD4+ T or CD8+ discreet (300 cells). During the secreting phase, the aggregated lymphoid increased to $3,000-4,000$ cells. 24 These findings led us to propose a hypothesis of a "vulnerability window" (starting with ovulation and lasting between 7-10 days until the secreting phase of the cycle) what suggests that endocrine alterations modulate the immune protection in a way that increases the probability of the HIV infection and sexually transmitted infections (STI). 24,20

Therefore, this percentage of increased collagen fibers in the uterine body in the group with Aids may be related to chronic HIV infection, since the induction of a cellular immune response characterized by the predominance of cytotoxic $\mathrm{T}$ lymphocytes, despite having a protective effect against HIV-1 genital infection, 25 are not sufficient to control viremia in patients with chronic infection. ${ }^{26}$ Once deposited in the vagina, the sperm moves rapidly into the cervix, uterine body, Fallopian tubes and ovaries, potentially leading to an exposure over a large and phenotypically diverse mucosal surface. ${ }^{27}$ These factors make women more vulnerable to sexually transmitted infections after sexual intercourse and may be responsible for the difficulty in establishing an efficient immunity against infections, since most sexually transmitted microorganisms are conveyed in large quantities of immunomodulatory seminal plasma. 28

In the histochemical and morphometric analysis in this study on autopsied female patients with and without Aids, the percentage of collagen fibers in the 
uterine body was higher in women with Aids. This indicates that an immune response to viral infection induces a greater production of these fibers as a mechanism to repair the caused lesions. Moreover, it reveals a failure of the organism in the attempt to keep the infection restricted to the cervix.

The interpretation of the parameters evaluated in the uterine body and cervix can be very useful in the diagnosis in the conditions associated to HIV infection. This may contribute to the patient's clinical conditions and life expectancy. In addition to favoring the development of therapeutic measurements that prevent the establishment of complications related to Aids.

\section{References}

1. Brasil. Ministério da Saúde. Departamento de DST, Aids e Hepatites Virais. Secretaria de Vigilância em Saúde. Boletim Epidemiológico: HIV e Aids. Brasília, DF; 2016. Ano V - $\mathrm{n}^{0}$ 01-26. Available in file://C:/Users/BIA/ Downloads/boletim_2016_1_pdf_16375.pdf Accessed in 13-11-17.

2. Cavellani CL, Rocha LP, Silva RSC, Oliveira LF, Faria HA, Olegario JG, Correa RR, Teixeira VP. The influence of Aids on the morphometric and immune status of the uterine cervix of autopsied patients. Curr HIV Res. 2011; 9 (8): 606-12.

3. Rocha LP, Silva R, Olegario J, Correa R, Teixeira VPA, Cavellani CL. Esophageal epithelium of women with AIDS: Thickness and local immunity. Pathol Res Pract. 2010; 206 (4): 248-52

4. Favarato GKNA, Silva ACS, Oliveira LFO, Ferraz, MLF, Teixeira VPA, Cavellani CL. Skin aging in patients with acquired immunodeficiency syndrome. Ann Diagn Pathol. 2016; 24 (10): 35-9.

5. Wira CR, Rodriguez-Garcia M, Patel MV. The role of sex hormones in immune protection of the female reproductive tract. Nat Rev Immunol. 2015; 15: 217-30.

6. Dixon LJ, Barnes M, Tang H, Pritchard MT, Nagy LE. Kupffer cells in the liver. Compr Physiol. 2013; 3 (2): 785-97.

7. Del Cornò M, Cappon A, Donninelli G, Varano B, Marra F, Gessani S. HIV-1 gp120 signaling through TLR4 modulates innate immune activation in human macrophages and the biology of hepatic stellate cells. J Leukoc Biol. 2016; 100 (3): 599-606

8. Tuyama AC, Hong F, Saiman Y, Wang C, Ozkok D, Mosoian A, Chen P, Chen BK, Klotman ME, Bansal MB. Human immunodeficiency virus (HIV)-1 infects human hepatic stellate cells and promotes collagen I and monocyte chemoattractant protein-1 expression: implications for the pathogenesis of HIV/hepatitis C virus-induced liver fibrosis. Hepatology. 2010; 52 (2): 612-22.

\section{Acknowledgments}

This present study was supported by the Conselho Nacional de Desenvolvimento Cientifico $e$ Tecnológico (CNPq) (National Council for Scientific and Technological Development), Coordenação de Melhoramento de Pessoal de Ensino Superior (CAPES) (Coordination of Improving Personnel in Superior Education), Fundação de Apoio à Pesquisa do Estado de Minas Gerais (FAPEMIG) (Research Support Foundation in Minas Gerais State) and Fundação de Ensino e Pesquisa de Uberaba (FUNEPU).( Teaching and Research Foundation in Uberaba).

9. Bauer M, Mazza E, Nava A, Zeck W, Eder M, Bajka M, Cacho F, Lang U, Holzapfel GA. In Vivo Characterization of the Mechanics of Human Uterine Cervices. Ann N Y Acad Sci. 2007; 1101 (1): 186-202.

10. Myers KM, Feltovich H, Mazza E, Vink J, Bajka M, Wapner RJ, Hall TJ, House M. The mechanical role of the cervix in pregnancy. J Biomech. 2015; 48 (9): 1511-23.

11. Yao W, Gan Y, Myers KM, Vink JY, Wapner RJ, Hendon CP. Collagen Fiber Orientation and Dispersion in the Upper Cervix of Non-Pregnant and Pregnant Women. PLoS ONE. 2016; 11 (11): e0166709.

12. Zork NM, Myers KM, Yoshida K, Cremers S, Jiang H, Ananth CV, Wapner RJ, Kitajewski J, Vink J. A systematic evaluation of collagen cross-links in the human cervix. Am J Obstet Gynecol. 2015; 212 (3): 321.e1-8.

13. Feltovich H, Hall TJ. Quantitative imaging of the cervix: setting the bar. Ultrasound Obstet Gynecol. 2013; 41 (2): $121-8$.

14. Myers K, Socrate S, Tzeranis D, House M. Changes in the biochemical constituents and morphologic appearance of the human cervical stroma during pregnancy. Eur J Obstet Gynecol Reprod Biol. 2009; 144: S82-9.

15. Gan Y, Yao W, Myers KM, Vink JY, Wapner RJ, Hendon CP. Analyzing three-dimensional ultrastructure of human cervical tissue using optical coherence tomography. Biomed Opt Express. 2015; 6 (4): 1090-108.

16. Centers for Disease Control and Prevention. HIV/AIDS Surveillance Report. Atlanta, US. 2003; (Vol. 15): 40. Available in https://www.cdc.gov/hiv/pdf/library/reports/ surveillance/cdc-hiv-surveillance-report-2003-vol-15.pdf.

17. Mastroianni CM, Lichtner M, Mascia C, Zuccalà P, Vullo V. Molecular mechanisms of liver fibrosis in $\mathrm{HIV} / \mathrm{HCV}$ coinfection. Int J Mol Sci. 2014; 15 (6): 9184-208.

18. Roszkiewicz J, Smolewska E. Kaleidoscope of autoimmune diseases in HIV infection. Rheumatol Int. 2016; 36: 1481-91 
19. Sturm-Ramirez K, Gaye-Diallo A, Eisen G, Mboup S, Kanki PJ. High levels of tumor necrosis factor-alpha and interleukin-1 beta in bacterial vaginosis may increase susceptibility to human immunodeficiency virus. J Infect Dis. $2000 ; 182$ (2): 476-73.

20. Wira CR, Rodriguez-Garcia M, Shen Z, Patel M, Fahey JV. The Role of Sex Hormones and the Tissue Environment in Immune Protection Against HIV in the Female Reproductive Tract. Am J Reprod Immunol. 2014; 72 (2): 171-81.

21. Coimbra DD, Lustosa JC, Sarmento DF, Lima RB, Pessoa OMN. Colagenoma eruptivo em paciente HIV+. An Bras Dermatol. 2008; 83 (2): 141-5.

22. Nazli A, Kafka JK, Ferreira VH, Anipindi V, Mueller K, Osborne BJ, Dizzell S, Chauvin S, Mian MF, Ouellet M, Tremblay MJ, Mossman KL, Ashkar AA, Kovacs C, Bowdish DM, Snider DP, Kaul R, Kaushic C. HIV-1 gp120 induces TLR2- and TLR4-mediated innate immune activation in human female genital epithelium. J Immunol. 2013; 191 (8): 4246-58.

23. Wira CR, Ghosh M, Smith JM, Shen L, Connor RI, Sundstrom P, Frechette GM, Hill ET, Fahey JV. Epithelial cell secretions from the human female reproductive tract inhibit sexually transmitted pathogens and Candida albicans but not Lactobacillus. Mucosal Immunol. 2011; 4 (3): $335-42$

Received on July 17, 2017

Final version presented on December 13, 2017

Approved on March 02, 2018
24. Wira CR, Fahey JV. A new strategy to understand how HIV infects women: identification of a window of vulnerability during the menstrual cycle. AIDS. 2008; 22 (15): 1909-17.

25. Iqbal Sm, Ball TB, Kimani P, Thottingal P, Embree JE, Fowke KR, Plummer FA. Elevated T cell counts and RANTES expression in the genital mucosa of HIV-1-resistant Kenyan commercial sex workers. J Infect Dis. 2005; 192 (5): 728-38.

26. Draenert R, Verril CL, Tang Y, Allen TM, Wurcel AG, Boczanowski M, Lechner A, Kim AY, Suscovich T, Brown NV, Addo MM, Walker BD. Persistent recognition of autologous virus by high-avidity CD8 $\mathrm{T}$ cells in chronic, progressive human immunodeficiency virus type 1 infection. J Virol. 2004; 78 (2): 630-41.

27. Racicot K, Cardenas I, Wunsche V, Aldo P, Guller S, Means RE, Romero R, Mor G. Viral infection of the pregnant cervix predisposes to ascending bacterial infection. $\mathrm{J}$ Immunol. 2013; 191 (2): 934-41.

28. Lima YAR, Alves MFC. O Sistema imune da mucosa do trato genital feminino e o impacto das doenças sexualmente transmissíveis. Rev Patol Trop. 2008; 37 (4): 295-309. 